\title{
Economic Valuation for Cultural and Passive Ecosystem Services Using a Stated Preference (Contingent Valuation Method (CVM)) Case of the Elgeyo Watershed Ecosystem, Kenya
}

\author{
Justus E. Eregae $\mathbb{D}^{1},{ }^{1}$ Paul Njogu ${ }^{(D},{ }^{1}$ Rebecca Karanja ${ }^{(D)},{ }^{2}$ and Moses Gichua ${ }^{3}{ }^{3}$ \\ ${ }^{1}$ Institute of Energy and Environmental Technology (IEET) of JKUAT, P.O. Box 62000-00200, Nairobi, Kenya \\ ${ }^{2}$ Plant and Microbial Sciences Department, Kenyatta University (KU), P.O. Box 43844-00100, Nairobi, Kenya \\ ${ }^{3}$ Botany Department, Jomo Kenyatta University of Agriculture and Technology (JKUAT), P.O. Box 62000-00200, Nairobi, Kenya
}

Correspondence should be addressed to Justus E. Eregae; jeregae@gmail.com

Received 25 April 2021; Accepted 2 August 2021; Published 16 August 2021

Academic Editor: Anna Źróbek-Sokolnik

Copyright (c) 2021 Justus E. Eregae et al. This is an open access article distributed under the Creative Commons Attribution License, which permits unrestricted use, distribution, and reproduction in any medium, provided the original work is properly cited.

\begin{abstract}
Valuation of ecosystem services (ESs) can be typical as use values and passive use values. However, the prevailing conventional markets provide economic instruments such as price tags to ecosystem use values, but rarely on passive use values. This is limited since it does not provide comprehensive ecological values that will adequately support rational decision-making processes regarding ecological conservation. The study adopted the contingency valuation method (CVM) where three hundred and eighty households of communities living within the Elgeyo watershed were sampled. The findings recorded $97 \%$ of the population was willing to pay for the ESs quoted. Individual maximum WTP ranged between 1 USD and 57.1 USD (cultural), 1 USD and 95.2 USD (bequest), and 1 USD and 76.2 USD (biodiversity conservation). The overall mean maximum WTP was 7.4 \pm 0.34 USD, $9.1 \pm 0.49$ USD, and $11.1 \pm 0.68$ USD for the cultural, bequest, and biodiversity, respectively. The multivariate regression (maximum WTP as a function of administrative location, education, income, sex, age, and livestock number) exhibited a significant difference regardless of multivariate criteria used, where Wilks' lambda has $F(75,203)=4.03, p<0.001$. The findings provide an economic value for nonuse values that can be incorporated in total economic valuation (TEV) studies locally as well as provide an impetus on payment of ecosystem services (PES) in Kenya.
\end{abstract}

\section{Background}

Ecosystem services (ESs) are direct and indirect benefits that the nature provides to the society, fundamental to human welfare, with genuine economic development, which people value [1-6]. System Environmental-Economic Accounting (SEEA) explicitly demonstrates the linkages between ESs with the economy and human livelihood program and how human development programs affect the stock and flow of ES in the future [7]. However, though the society depends on the nature for its survival and development, its economic value is invisible in policy and decision-making processes. Benefit and the subsequent degradation cost of our ecosystems have, in many instances, gone largely unnoticed [8]. Valuation of ESs becomes essentially important to not only account for the benefit acquired from the nature but also express and report in monetary terms the impact and cost of degrading our ecosystems and biodiversity [9]. Furthermore, the valuation of the ecosystem and biodiversity is a prerequisite for the establishment of a market-based mechanism such as payment of ecosystem services to reward conservation efforts and promote the enhanced flow of ESs [10]. Taking cognizance of the nature and benefits provided would be regarded as step one, but an estimation of ES worthiness more so in monetary terms would be more persuasive in decision making and, thus, encourage the incorporation of the same in their decisions $[9,11]$.

The total economic valuation (TEV) framework has broadly grouped ESs as "use" and "nonuse/passive" values $[4,8]$. Assessment and measurement of ESs could be 
undertaken using various metrics that can either be nonmonetary and nonnumerical or numerical and monetary. All these are dependent on the services or goods being quantified, time, resources available, and the significance of the valuation study on a decision to be undertaken. Valuation of ESs, particularly in monetary terms, is complex, and in most cases, a small subset of ecosystem and biodiversity services is available in our conventional markets and where necessary "priced" [5]. Commonly, "use values" have market prices and, thus, it is simpler to attach a monetary value while "nonuse values/passive use values" have no market "price" primarily because of their public goods and service nature $[12,13]$ and are, thus, more complex to ascribe a monetary unit. The prevailing scenario is limited since it does not provide comprehensive ecological values that will adequately support rational decision-making processes in regards to biological conservation in its entirety. That notwithstanding, conventional techniques and tools have been developed and adopted in valuation including nonuse/passive use services that are largely categorized as revealed and stated preference. Albeit substantial criticism on their robustness, they are conventionally applied while bearing shortcomings as pointed out. Fundamentally, on the hypothesis that the monetary values of these services are contingent on societal preference, choices, and tradeoffs, overall, valuation of these services is aimed at unravelling the complex socioeconomic and ecological linkages to influence sound decision making as the society envisages a genuine development progress. More so, as the society advances, incentivization of ecosystem and biodiversity conservation and its incorporation in projects and policy appraisals is carried out.

The economic valuation of ESs is rapidly developing as the main logical mechanism available to support rational decision making on the conservation of nature [14, 15]. Appreciating, accounting, and expressing, in a monetary unit, the value of ES is essential in advancing a new policy direction, particularly on conservation and management of nature [9]. The valuation concept is meant to provide information on the economic status of natural resources and provide the cost of degradation both at the local and international development discourse that would otherwise make an irrational decision on biodiversity conservation [5]. This is also aimed at accounting and reporting the monetary impact of ecosystem and biodiversity changes that would primarily not be reported in conventional markets and particularly those not connected to human social welfare [16]. Enhanced ecosystem conservation would translate to improved and continuous provision of ecosystem services and, thus, enhanced human well-being.

Passive use values are ecosystem goods and services that the society attaches to ecological systems not necessarily connected to current or future beneficiaries, rather intrinsic values of nature existence [17-19]. They have been the subject of the evolving economic literature since the mid$20^{\text {th }}$ century when the society started discussing the importance of existence and aesthetic values to nature conservation [20]. Different terminologies have been utilized to define these services; however, in recent years, these values have been defined in the context of existence and bequest values to underscore the utilitarian dimension of such ecosystem values in economics [21, 22]. That notwithstanding, these values provide fundamental and most convincing incentives, particularly for conservation of nature and biological diversity $[20,23]$ more so locally (Kenya).

It is worth noting not all ESs are readily traded in conventional markets and, thus, complexity in the apportionment of monetary units [24]. There are, however, applicable conventional nonmarket valuation techniques that are used to apportion value to passive use values. These include stated preference (contingent valuation model (CVM), discrete choice experiment model, and conjoint valuation) and revealed preference (travel cost method (TC)); time cost method; and hedonic pricing method (HPM)) [25]. The monetary unit for passive or nonuse values is defined and measured on the pretext of willingness to pay (WTP) within the framework of neoclassical economics [20]. Despite reporting substantial shortcomings, stated preference has been the most common valuation technique used for attaching economic value to nonuse values [20,26-28]. Similarly, the CVM has shown to be relatively straightforward since it does not require an explicit relationship between nonmarketed goods and product market prices [20]. All it requires is setting up a hypothetical scenario and presenting the same to the targeted respondent and subsequently elicit maximum willingness to pay that represents the economic values of the quoted ecosystem service indirectly [29]. According to the work in [20], the mean minimum economic value for nonuse resources using the choice experiment model ranges between 25 and $40 \%$ less than the common mean WTP reported. The CVM is used as a market-based instrument to compute the maximum mean WTP in exchange of either to enhance ecosystem public goods and service or fund payment "vehicle" schemes more so for nonuse values as it seeks to express changes in utility in monetary terms [30,31].

The Elgeyo Hills watershed prides with exceptional resources ranging from pristine sceneries; unique biodiversity; geology; and mineral resources to favourable climate among others. The ecosystem provides ecosystem goods and services such as freshwater, food production, beautiful sceneries, and sociocultural site among others. Although the ecosystem is critical both locally and internationally, it is, however, under immense pressure from anthropogenic drivers essentially from other competing land uses and programs. This has led to massive degradation and decline in the state of resources over the past years leading to reduced stock and flow of ecosystem goods and services. This is projected to impact negatively on community well-being and the national economy soon. The ecosystem is also part of Lake Turkana and Victoria subbasins, and thus, continued degradation would pose a negative consequence on the sustenance of these critical lakes and, thus, not able to provide and sustain the growing human socioeconomic development agenda in the region [32].

\section{Materials and Methods}

2.1. Study Area. The Elgeyo watershed is one of the proposed water towers in the country and traverses two counties though largely on Elgeyo Marakwet County with a small section on 
Uasin-Gishu County. It is located between $35^{\circ} 20^{\prime \prime}$ and $35^{\circ} 45^{\prime \prime}$ east longitude and $0^{\circ} 10^{\prime}$ and $0^{\circ} 20^{\prime}$ north latitude and borders Baringo County on the East, Uasin-Gishu on the South, and Trans Nzoia and West Pokot on the North. It covers 47073.7 ha including a gazetted forest covering 22,080.6 ha and farmland covering 24993.1 ha. The gazetted forest includes 8,793.1 ha plantation (39.8\%) and 8,326.38 ha indigenous (37.7\%), while other categories bushland and grassland cover 4,960.52 ha (22.5\%) [33]. The gazetted forest includes Kaptagat (5663.6 ha), Sabor (4047 ha), Kipkabus (6503.6 ha), Penon (3220 ha), and Kessup (2647 ha) (Figure 1). The watershed falls within three major agroecological zones, high-altitude region, and moorland; escarpment and valley; and lowland. The ecosystem has a relatively cool climate with varied rainfall levels across the various agroecological zones. The average rainfall is $700 \mathrm{~mm}$ in the semiarid Kerio Valley and $1700 \mathrm{~mm}$ in the highlands. The rainy season is between March and September with a maximum recorded in May and August and a minimum in January. Seasonal variation increases in the more arid areas of the valley and reliability decrease. Temperatures in the valley record as high as $33^{\circ} \mathrm{C}$ more so in the lower altitude areas. The annual evapotranspiration rate is approximated at $1985.09 \mathrm{~mm}$. The altitude varies from $900 \mathrm{~m}$ above sea level in the Kerio Valley to over $3350 \mathrm{~m}$ above sea level in the highlands which gives rise to considerable differences in climatic conditions. The slope varies from $2 \%$ in the valleys to $37 \%$ in the hills [34].

Elgeyo Marakwet County has a population of 454,480 (227,317 male and 227,151 female), 99,119 households with an intercensus population rate of $2.7 \%$. Keiyo South Constituency is the most populous one with a total of 120,750 and Marakwet East has the least with 97,041, while Keiyo North has a population of 99,176 and Ainabukoi and Moiben in Uasin-Gishu have a population of 138,184 and 181,338, respectively. Elgeyo Marakwet County has an average population density of 150 persons per square kilometer while Uasin-Gishu has a density of 342 persons per square kilometer [35]. The labour force (15-64 years age bracket) accounts for 49.7 percent of the total population $[34,36]$.

2.2. Survey Design and Data Handling. The study adopted a cross-sectional approach where the interviews for the sampled population were carried at one point in time between December 2020 and January 2021 through administration of structured questionnaires. Stratified sampling was employed where the study area was divided into the smallest administrative units (sublocation) as the enumeration area (EA). A fraction was generated based on the population of the enumeration area divided by the total population. This was used to populate the primary sample unit after multiplying with a total sample size of 384 generated by Mugenda and Mugenda [37]. This stratified sampling design was preferred to others since it offered a better opportunity not only for the overall population but also individuals at the smallest sample had a chance of being represented in the survey.

The study elicited the willingness to pay from a sample of households living around the Elgeyo watershed whereby it first sought authority from local state institutions, local administration, and community before commencement with primary data collection. The local elders were also consulted who ultimately supported both in guiding the research team and providing indigenous knowledge during the entire study period.

The design on the contingent valuation method (CVM) questionnaire was a single-bound dichotomous choice where the maximum willingness to pay was elicited through either yes or no question. Similarly, inquiry on household socioeconomic characteristics hypothesized to influence the maximum bid value by the target population was incorporated in the questionnaire. They included respondent age, sex, education, income, the distance to the ecosystem, land size, household size, and household leadership characteristics among others. The questionnaire was pretested together with all the research assistance before the actual survey.

The questionnaire had four parts: firstly, provoking environmental conservation conscience on the benefit accrued from the ecosystem and narrowing to nonuse ESs (cultural/spiritual values, bequest, and biodiversity conservation) as quoted, secondly the hypothesis of enhanced services' stock and flow after undertaking some policy action and demonstrating the contrary on maintenance of status, then the single dichotomous question on whether they agree with the status of the benefit demonstrated with both the scenarios, and lastly, the proposed bid from which the respondents were to choose from, in this case, between 1 USD and 95.2 USD. The bid range was adopted from the commonly used WTP values reported to range from 1 to 200 USD, one being the minimal and two hundred being the highest [38]. Eleven (KES 100, 500, 1000, 1500, 2000, 3000, $4000,5000,6000,8000$, and 10,000) bid options provided wide range the respondents were to choose from. This provided a range to obtain the mean lowest as well as the highest bid for the services quoted [39].

The study considered every bid stated by the respondent; however, zero values were considered invalid if reported as a protest. The protest, in this case, is where the respondent perceives the value is zero since it is not "their" role to conserve either on the basis that it is the government's responsibility or lack of trust in institutions vested with the management of the proposed scheme. Furthermore, individuals who did not understand the concept were also excluded from the survey.

Overall, the study intended to first establish the mean estimate WTP for local communities living around the watershed and, secondly, compare the mean value across the various factors hypothesized to influence the actual economic value stated. The data regenerated were both quantitative and qualitative, thus necessitating the use of descriptive statistics and correlative and comparative analysis where a mix of linear and nonlinear regression was utilized.

\section{Results}

3.1. Household Sample. The study sampled 380 households from the population living around the watershed. The distribution was based on the proportion of primary sample point areas (administrative units). The sampled household was spread across the households living around the 


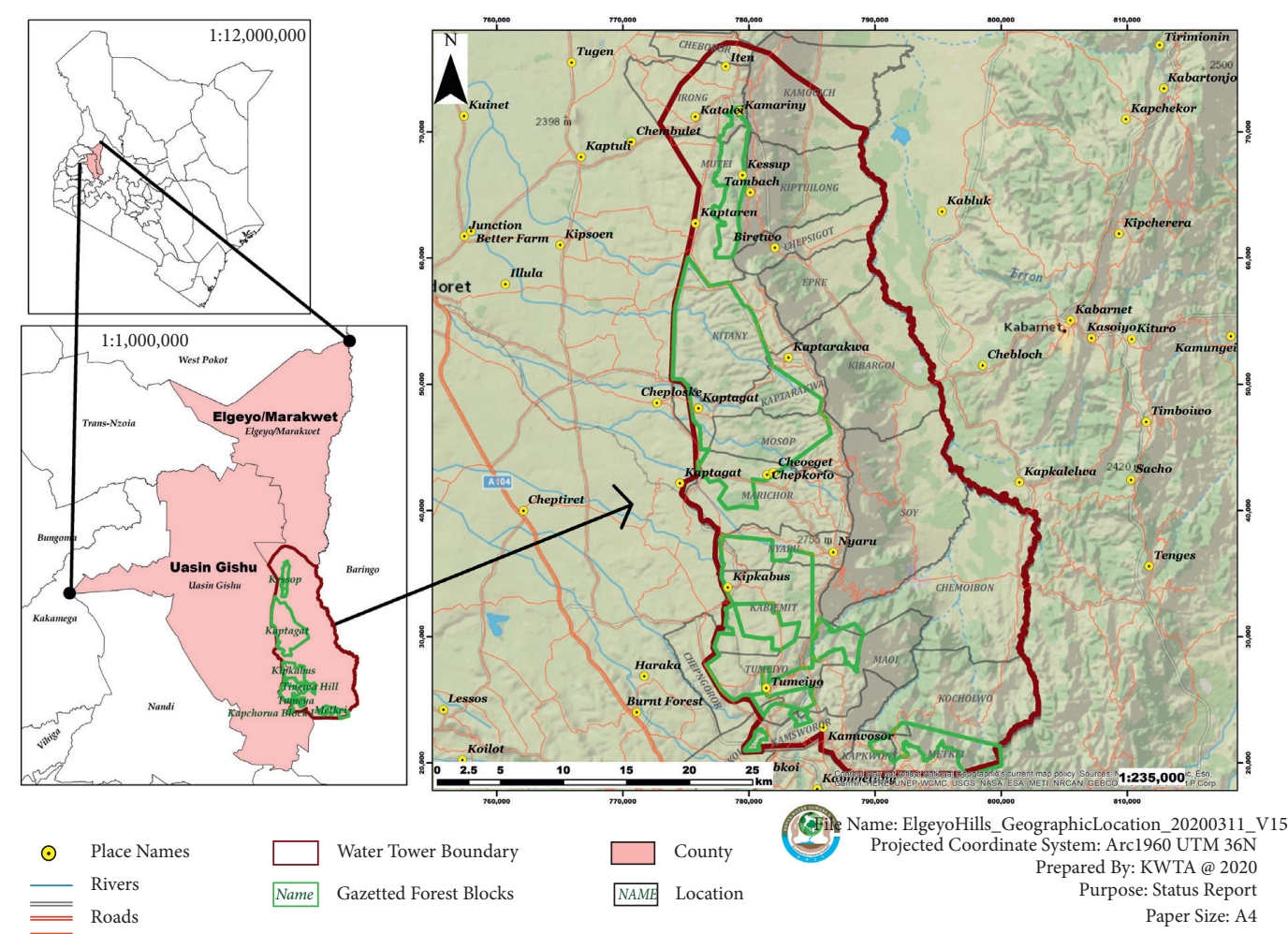

FIgURE 1: Map of the Elgeyo Hills watershed traversed by administrative locations (source: KWTA).

watershed within a $10 \mathrm{~km}$ radius from the state forest (Figure 2). The basis for community within the $10 \mathrm{~km}$ buffer zone was on assumption that individuals within this radius actively interact more frequently with the ecosystem more than those living outside the ten kilometers radius.

3.2. Socioeconomic Characteristics. Fifty-seven percent (57\%) of the respondents were female, while about $43 \%$ were male. About $67 \%$ of the respondents were in the cohort of age between 36 and 60 years, while about $10 \%$ and $23 \%$ of the respondents represented above 60 years and youth cohort, respectively. The majority of the inhabitants fall within the active and youthful cohort, a population that is likely to grow. About $97 \%$ of the respondents had attended school while $3 \%$ had not. Twenty percent of the respondents had attained postsecondary education with only about one percent reporting to have attained postgraduate studies. The main occupation of the inhabitants was crop farming as reported by about $78 \%$ of the respondents (Table 1 ).

The youngest respondent was aged 20 years while the oldest was 85 years with a mean of about 45 years. The household size ranged from one and twenty individuals with a mean of six persons, while land ownership ranged from 0.25 and over 100 acres with a mean of 6.2 acres. The community is agropastoral owning between 1 and $>30$ livestock reported in the study as tropical livestock unit (TLU) at a mean of about four. The household net annual income ranged between KES 1,000/ and over 3 million with a mean of KES 170,000/. The period lived by the respondent in the area varied between 1 and 79 years with a mean of 38 years. This suggests that the majority of the inhabitants have lived in the study area for more than three decades and there are no immigrants. The beneficiaries of the watershed reside between 500 meters to $35 \mathrm{~km}$ away from the ecosystem, though other resource users (water resource) lived farther away (Table 2).

3.3. Perception on the Benefit and Importance of Elgeyo to Nonuse Services. The survey inquired on whether the local community benefited from cultural/spiritual and biodiversity conservation. The majority of the respondents, however, reported not to be utilizing cultural, recreational, and biodiversity conservation services as recorded with about $80 \%$ of the population (Figure 3).

That notwithstanding, the community perceived the ecosystem as critically important as confirmed by the responses where, for instance, about $60 \%$ of the respondents reported that the watershed was important for biodiversity conservation while about $4 \%$ reported it as least important (Table 3). About $51 \%$ of the community, on the other hand, perceive the ecosystem as important for cultural and spiritual services, while about $10 \%, 14 \%$, and $18 \%$ perceive it as least important, more important, and most important (Table 4). In other words, on a scale of $1-5$, one being the least important and 5 being the most important, the study would report that the majority of the community would rate the ecosystem at three (3) out of five (5) on perceived importance on nonuse values.

3.4. Maximum Willingness to Pay (WTP) for Nonuse Ecosystem Service. Individual willingness to pay estimates for nonuse value estimates was computed where per capita 


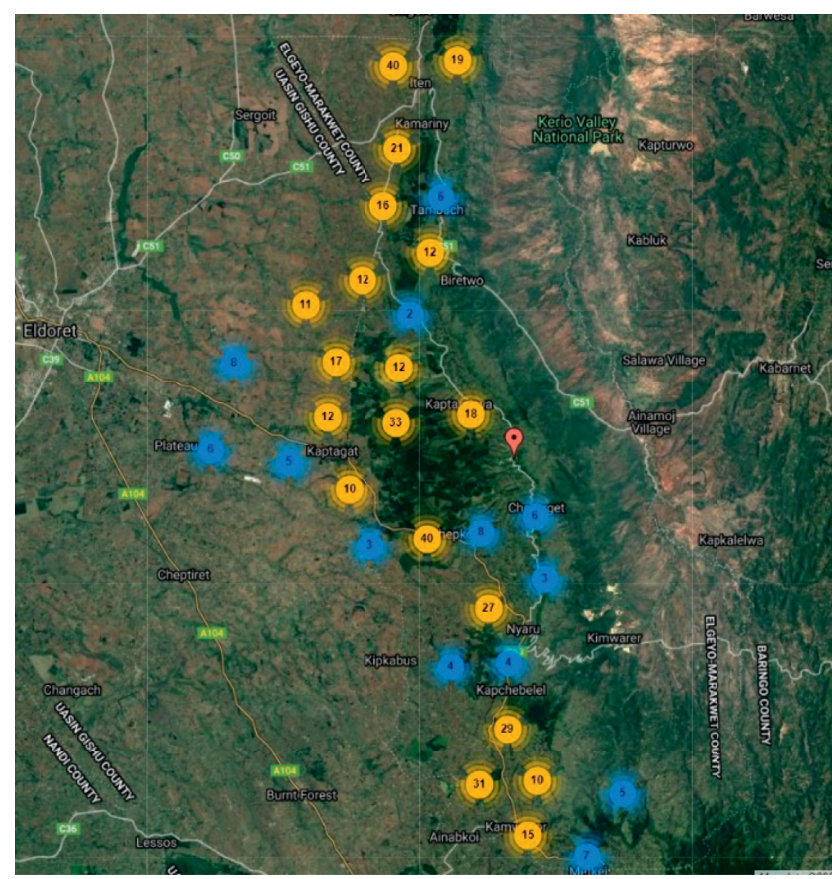

FIgURE 2: Sampled household distribution around the Elgeyo watershed.

values ranged between 1 USD and 95.2 USD. Overall, the mean \pm SD WTP per capita per annum was estimated at $7.4 \pm 0.3$ USD, $9.1 \pm 0.5$ USD, and $11.1 \pm 0.7$ for the cultural, bequest, and biodiversity conservation, respectively (Table 5). Overall, a majority (97\%) of the population was willing to pay for the abovementioned services while only $3 \%$ were not willing to pay.

Although the majority of communities around the ecosystem were willing to participate and pay for nonuse, about $51 \%$ on each category quoted less than 5USD, while about $30 \%$ were willing to pay between 5.1 USD and 10 USD with about $2 \%$ willing to pay more than 40 USD. Overall, the majority $(\sim 80 \%)$ of the respondents were willing to pay between 1 USD and 10 USD while less than $20 \%$ of the respondents were willing to pay more than 10 USD for all the services quoted and bided (Table 6).

Worth noting, overall, the mean maximum WTP stated varied significantly across administrative units and key socioeconomic parameters for all ESs quoted. The multivariate regression exhibited statistical significance, regardless of the type of multivariate criteria used where, for instance, Wilks' lambda has $F_{(75,203)}=4.03, p<0.05$. The model explains $63 \%, 78 \%$, and $69 \%$ of the variance for cultural, bequest, and biodiversity, respectively (Table 7). The findings suggest that communities in one administrative unit will value nonuse services differently from their peers from the other administrative unit fundamentally based on their understanding of ecosystem services and perception.

Though administrative location had a greater influence on the mean maximum significant difference, the study also recorded socioeconomic parameters to influence the variance on the mean maximum WTP across the
ES. The socioeconomic values examined included the household income, household size, sex, age of the respondent, land size, period lived, distance from the forest, and the tropical livestock unit (TLU). The parameters were regressed against the mean WTP of cultural, bequest, and sustainability/biodiversity services as presented hereunder.

3.5. Cultural Services. Linear regression on maximum WTP for cultural services as a function of socioeconomic parameters as aforementioned exhibited a significant difference with $F_{(9,304)}=5.10, p<0.05$. The difference in mean maximum on the socioeconomic parameters on the study can be explained by about $11 \%$ (adj. $R$-squared $=0.106$ ) of the analysis. Furthermore, individual parameters at a $95 \%$ confidence level indicated that education, age, and income influence the maximum WTP stated by the community within the watershed. The higher level of education the individual attained is likely to increase the maximum WTP by KES 84.70 on cultural values, while an increase in age reduces the max WTP by at least KES 11.33. Household income, though low, records to influence the maximum willingness to pay by KES 4.00 in every KES 10,000 increase on income (Table 8). Another important parameter, though not significant at $95 \% \mathrm{CL}$, is the period an individual lived in the area, and it enhances the value by KES 5.20 more than newer individuals. This suggests that community members that have lived longer understand the flow of ESs and attach higher value and are, thus, willing to pay a higher amount on cultural/spiritual services compared to members that are newer to the area. This could be explained on the basic understanding on the education level and younger longer life expectancy compared to older while an individual that lived in the area longer had experienced and enjoyed cultural/spiritual services more than new individuals.

3.6. Bequest Ecosystem Services. The regression analysis exhibited a significant difference in the maximum WTP for bequest against the parameters listed with $F_{(9,304)}=4.70$, $p<0.05$. The model explains about $10 \%$ of the variance on maximum WTP in the study with adj. $R$-squared equivalent to 0.096 . The socioeconomic parameter about bequest services exhibited varied significance, where sex, age, and TLU recorded influence on the maximum WTP. An increase in the age of individuals reduces the maximum WTP by about KES 16.76, while the likelihood of male respondents' enhanced amount was stated by KES 249.00 and vice versa on the female. Similarly, the higher the livestock owned by $\mathrm{HH}$, the higher the maximum WTP by KES 34.90. The findings suggest that younger people would like to preserve the ecosystem for future use while the older population thinks otherwise; thus, the WTP value is lower. Male individuals seem to attach a higher value to bequest compared to their female counterparts. Similarly, people who had lived longer in the watershed may have benefited from the watershed and, thus, justify higher WTP compared to new members of the community that may have 
TABLE 1: Respondent demographic statistics.

\begin{tabular}{|c|c|c|c|c|}
\hline Variable & Parameters & Frequency & Valid percent & Cumulative percent \\
\hline \multirow{2}{*}{ Sex } & Male & 160 & 42.7 & 42.7 \\
\hline & Female & 215 & 57.3 & 100.0 \\
\hline \multirow{3}{*}{ Age cohort } & $19-35$ & 83 & 23.2 & 23.2 \\
\hline & $36-60$ & 239 & 66.9 & 90.2 \\
\hline & $60+$ & 35 & 9.8 & 100.0 \\
\hline \multirow{6}{*}{ Education } & Graduate & 11 & 2.9 & 3.2 \\
\hline & None & 13 & 3.5 & 6.7 \\
\hline & Postgraduate & 3 & 0.8 & 7.5 \\
\hline & Primary & 114 & 30.4 & 37.9 \\
\hline & Secondary & 170 & 45.3 & 83.2 \\
\hline & Tertiary & 63 & 16.8 & 100.0 \\
\hline \multirow{7}{*}{ Main occupation } & Business & 45 & 12.0 & 12.5 \\
\hline & Crop farmer & 293 & 78.1 & 90.7 \\
\hline & Juakali/craftsman & 3 & 0.8 & 91.5 \\
\hline & None & 3 & 0.8 & 92.3 \\
\hline & Pastoralists & 1 & 0.3 & 92.5 \\
\hline & Retired (pensioner) & 4 & 1.1 & 93.6 \\
\hline & Salaried/employed & 24 & 6.4 & 100.0 \\
\hline
\end{tabular}

TABle 2: Descriptive statistics on HH socioeconomics.

\begin{tabular}{lccccc}
\hline Socioeconomic parameters & $N$ & Minimum & Maximum & Mean & Std. deviation \\
\hline Age & 357 & 20 & 85 & $79.2 \pm 0.6$ & $38.4 \pm 0.9$ \\
Period lived in the area & 359 & 1 & 1 & 20 & $6.2 \pm 0.1$ \\
Total HH size & 368 & 0.25 & 100 & $6.2 \pm 0.5$ & 17.4 \\
Land size & 372 & 0 & 35.2 & $3.9 \pm 0.2$ & 2.2 \\
TLU & 374 & $1,000.00$ & $3,060,000.00$ & $173,140.90 \pm 13,226.1$ & 3.9 \\
Net income (KES) & 334 & 1 & 640 & $122.7 \pm 6.7$ & $241,716.39$ \\
Time (min) to the forest & 370 & 0.05 & 35 & $3.9 \pm 0.3$ & 129.6 \\
Distance (km) to the forest & 369 & & & 4.9 \\
\hline
\end{tabular}

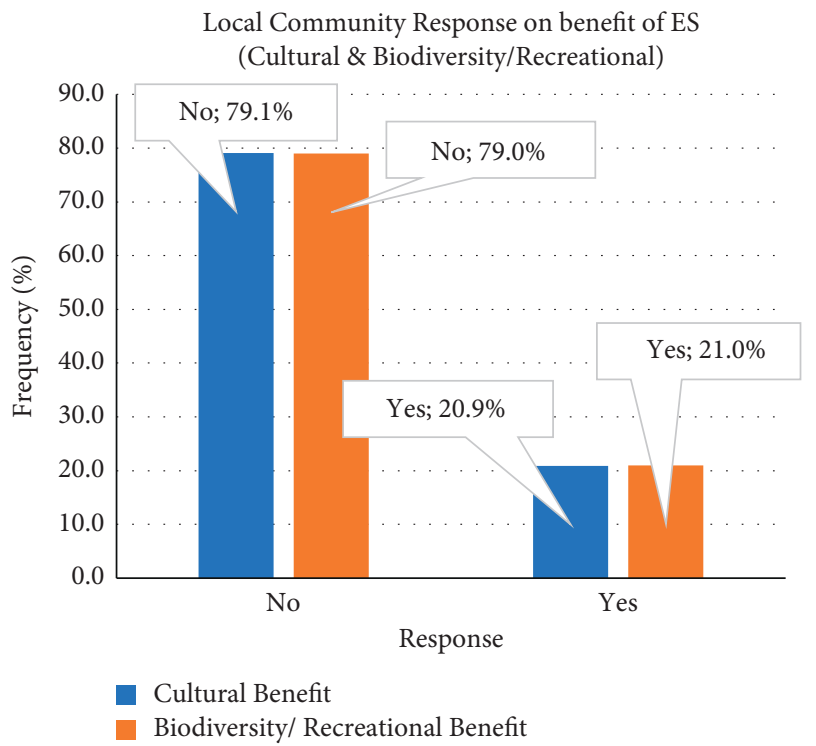

Figure 3: Perception on forest benefit on cultural and biodiversity service.

not seen its full benefit (Table 9). Value on TLU would be explained by the benefit of grazing areas, where the community would preserve the ecosystem and possibly
TABle 3: Perception on the importance of the ecosystem on biodiversity conservation.

\begin{tabular}{lcccc}
\hline \multirow{2}{*}{ Importance for future use values } & \multicolumn{4}{c}{ WTP category } \\
& No & Yes & Total & Percent \\
\hline Least important & 0 & 14 & 14 & $\mathbf{3 . 8}$ \\
More important & 0 & 58 & 58 & $\mathbf{1 5 . 8}$ \\
Most important & 5 & 59 & 64 & $\mathbf{1 7 . 4}$ \\
Somewhat important & 0 & 14 & 14 & $\mathbf{3 . 8}$ \\
Important & 4 & 213 & 217 & $\mathbf{5 9 . 1}$ \\
Total & 9 & 358 & 367 & $\mathbf{1 0 0 . 0}$ \\
Percent & $\mathbf{2 . 5}$ & $\mathbf{9 7 . 5}$ & $\mathbf{1 0 0 . 0}$ & \\
\hline
\end{tabular}

take care of the livestock in, for instance, times of drought. Worth noting, period lived, distance, land size, household income, and size do not influence the decision of the community to preserve the ecosystem for future use.

3.7. Biodiversity Conservation. The linear regression analysis exhibited a significant difference in maximum WTP as a function of socioeconomic traits with $F_{(9,264)}=3.08, p<0.05$ onetheless, as the society. The model explains about $8 \%$ of the significant difference in the study as provided by the adj. $R$-squared equivalent of 0.0846 . At $95 \%$ confidence level, age, income, and TLU are cited as factors determining the 
TABLE 4: Perception on the importance of the ecosystem to cultural services.

\begin{tabular}{|c|c|c|c|c|}
\hline \multirow{2}{*}{ Importance of ecosystem cultural/spiritual services } & \multicolumn{3}{|c|}{ WTP category } & \multirow{2}{*}{ Percent } \\
\hline & No & Yes & Total & \\
\hline Least important & 1 & 34 & 35 & 9.5 \\
\hline More important & 0 & 51 & 51 & 13.8 \\
\hline Most important & 7 & 59 & 66 & 17.9 \\
\hline Somewhat important & 0 & 27 & 27 & 7.3 \\
\hline Important & 1 & 189 & 190 & 51.5 \\
\hline Total & 9 & 360 & 369 & 100.0 \\
\hline Percent & 2.4 & 97.6 & 100.0 & \\
\hline
\end{tabular}

TABle 5: Descriptive statistics on the maximum willingness to pay for nonuse ESs.

\begin{tabular}{|c|c|c|c|c|c|c|}
\hline Non use ES & $N$ & Minimum & Maximum & Mean & Std. error & Std. deviation \\
\hline Cultural (US\$) & 361 & 0.95 & 57.14 & 7.43 & 0.34 & 6.37 \\
\hline Bequest (US\$) & 361 & 0.95 & 95.24 & 9.10 & 0.49 & 9.35 \\
\hline Biodiversity (US\$) & 319 & 0.95 & 76.19 & 11.14 & 0.68 & 12.12 \\
\hline Valid $N$ (listwise) & 274 & & & & & \\
\hline
\end{tabular}

TABle 6: Frequency (\%) across the maximum WTP value cohort.

\begin{tabular}{lccc}
\hline Value range (USD) & Cultural & Bequest & Biodiversity \\
\hline $1-5$ & 51.0 & 51.0 & 51.1 \\
$5.1-10$ & 30.2 & 30.2 & 28.2 \\
$10.1-15$ & 6.4 & 6.4 & 6.9 \\
$15.1-20$ & 7.2 & 7.2 & 7.8 \\
$20.1-30$ & 2.5 & 2.5 & 2.8 \\
$30.1-39$ & 0.8 & 0.8 & 0.9 \\
$40-49$ & 1.7 & 1.6 & 1.9 \\
$91 \geq 95$ & 0.3 & 0.3 & 0.3 \\
Grand total & $\mathbf{1 0 0 . 0}$ & $\mathbf{1 0 0 . 0}$ & $\mathbf{1 0 0 . 0}$ \\
\hline
\end{tabular}

maximum WTP on sustainable biodiversity conservation. The finding suggests that younger people support conservation of biodiversity while the older population thought otherwise as justified by reduced maximum WTP by KES 26.72 in every older year attained. The household with more livestock attached a higher value to biodiversity conservation. An increase in TLU increases the maximum WTP by KES 62.77. The increase in household income, however, impacts negatively on the value of sustainable biodiversity conservation wherein every KES 10,000/increase on household income reduces the maximum WTP by KES 10.00. The other factors though with a $p$ value slightly above 0.05 are sex and period lived in the area at a $5 \%$ error level. Male individuals attached a higher value to biodiversity conservation services than their female counterparts. Furthermore, the longer period lived in the area had highly enhanced the maximum WTP by at least KES 10.35 to biodiversity conservation (Table 10). Education, household size, and distance from the forest were not factors influencing sustainable biodiversity conservation.

\section{Discussion}

4.1. Benefit and Level of Importance of Nonuse ESs. The majority of the respondents, however, reported not to be utilizing cultural, recreational, and biodiversity conservation services as recorded with about $80 \%$ of the population. That notwithstanding, the findings did not, in any way, contradict the criticality of the ecosystem in the provision of ESs quoted as would be confirmed by a majority (>90\%) of the respondents that reaffirmed the importance of the Elgeyo ecosystem. This is similar to the sentiment shared in a study in Uganda on WTP on the importance of existence and sustainability values [39]. However, the response of the majority not benefiting implies a lack of understanding on how biodiversity conservation is connected with community socioeconomic, livelihood, and wellbeing [40]. Nonetheless, the community perceived the ecosystem as critically important as confirmed by the responses where, for instance, about $60 \%$ of the respondents reported that the watershed was important for biodiversity conservation while about $4 \%$ reporting it as least important. On a scale of $1-5$, one being the least important and 5 being the most important, the study would report that the majority of the community ation as a function of socioeconomic parameters. would rate ecosystem at three (3) out of five (5) on perceived importance on nonuse values. This confirms the indirect benefits associated with nonwood forest products accrued by the community; even though not benefiting directly, they would still be motivated to conserve it. These are similar to the sentiments made in a study in Cambodia on nontimber products [41].

4.2. Maximum Willingness to Pay (WTP) for Nonuse Ecosystem Service. Albeit the local community appreciating the nonuse values the maximum WTP would be influenced by socioeconomic traits and the jurisdiction. Though the administrative location had a greater influence on the mean maximum significant difference, the study also recorded socioeconomic parameters to influence the variance on the mean maximum WTP across the ESs. The socioeconomic traits examined included the household income, household size, sex, age of the respondent, land size, period lived, distance from the forest, and the tropical livestock unit (TLU). 
TABLE 7: Multivariate regression on cultural and passive/nonuse values) as a function of area and socioeconomic parameters.

\begin{tabular}{|c|c|c|c|c|c|c|c|}
\hline \multirow[t]{2}{*}{ Source } & \multicolumn{2}{|r|}{ Statistic } & \multirow[t]{2}{*}{ Df } & \multicolumn{3}{|c|}{$F(\mathrm{df} 1, \mathrm{df} 2)=\mathrm{F}$} & \multirow{2}{*}{$\begin{array}{l}\text { Prob }>F \\
0.0000 \mathrm{a}\end{array}$} \\
\hline & $\mathrm{W}$ & 0.0639 & & 225.0 & 603.7 & 4.03 & \\
\hline \multirow{3}{*}{ Model } & $\mathrm{P}$ & 1.6381 & \multirow{3}{*}{75} & 225.0 & 609.0 & 3.26 & $0.0000 \mathrm{a}$ \\
\hline & $\mathrm{L}$ & 5.7833 & & 225.0 & 599.0 & 5.13 & $0.0000 \mathrm{a}$ \\
\hline & $\mathrm{R}$ & 4.3441 & & 75.0 & 203.0 & 11.76 & $0.0000 \mathrm{u}$ \\
\hline & Residual & & 203 & & & & \\
\hline Equation & & Obs & Parameters & RMSE & “ $R^{2 »}$ & $F$ & $P$ \\
\hline Cultural & & 279 & 76 & 415.81 & 0.64 & 4.70 & 0.0000 \\
\hline Bequest & & 279 & 76 & 515.85 & 0.78 & 9.77 & 0.0000 \\
\hline Biodiversity & & 279 & 76 & 825.75 & 0.69 & 5.89 & 0.0000 \\
\hline
\end{tabular}

$\mathrm{e}=$ exact, $\mathrm{a}=$ approximate, $\mathrm{u}=$ upper bound on $\mathrm{F} . \mathrm{W}=$ Wilks' lambda $\mathrm{L}=$ Lawley-Hotelling trace, $\mathrm{P}=$ Pillai's trace, $\mathrm{R}=$ Roy's largest root.

TABLE 8: Cultural values as a function of socioeconomic parameters.

\begin{tabular}{|c|c|c|c|c|c|}
\hline Source & SS & Df & MS & \multicolumn{2}{|c|}{$\begin{array}{c}\text { Number of Obs }=314 \\
F_{(9,304)}=5.10\end{array}$} \\
\hline Model & 12782726.6 & 9 & 1420302.95 & \multicolumn{2}{|c|}{ Prob $>F=0.0000$} \\
\hline Residual & 84630012.3 & 304 & 278388.20 & \multirow{2}{*}{\multicolumn{2}{|c|}{$\begin{array}{c}R \text {-squared }=0.13 \\
\text { Adj. } R \text {-squared }=0.11 \\
\text { Root MSE }=527.63\end{array}$}} \\
\hline Total & 97412738.9 & 313 & 311222.81 & & \\
\hline Cultural/spiritual & Coef. & Std. err. & $T$ & $p>|t|$ & Beta \\
\hline Sex, male & 7.89 & 69.10 & 1.13 & 0.261 & 0.07 \\
\hline Education & 84.68 & 36.93 & 2.29 & 0.023 & 0.13 \\
\hline Period lived & 5.18 & 2.79 & 1.86 & 0.064 & 0.16 \\
\hline Distance $(\mathrm{km})$ & -8.64 & 6.44 & -1.34 & 0.181 & -0.08 \\
\hline $\mathrm{HH}$ size & 21.24 & 13.26 & 1.60 & 0.110 & 0.09 \\
\hline Land size & 4.99 & 4.63 & 1.08 & 0.282 & 0.08 \\
\hline TLU & 12.71 & 9.99 & 1.27 & 0.204 & 0.09 \\
\hline Income & 0.000403 & 0.0001319 & 3.05 & 0.002 & 0.18 \\
\hline Age & -11.33 & 3.91 & -2.90 & 0.004 & -0.24 \\
\hline Cons & 556.90 & 169.86 & 3.28 & 0.001 & \\
\hline
\end{tabular}

TABLE 9: Bequest values as a function of socioeconomic parameters.

\begin{tabular}{|c|c|c|c|c|c|}
\hline Source & SS & Df & MS & \multicolumn{2}{|c|}{$\begin{array}{c}\text { Number of Obs }=314 \\
F_{(9,304)}=4.70\end{array}$} \\
\hline Model & 30159486.6 & 9 & 3351054.07 & \multicolumn{2}{|c|}{ Prob $>F=0.0000$} \\
\hline Residual & 216780927 & 304 & 713095.156 & \multirow{2}{*}{\multicolumn{2}{|c|}{$\begin{array}{c}R \text {-squared }=0.1221 \\
\text { Adj. } R \text {-squared }=0.0961 \\
\text { Root MSE }=844.45\end{array}$}} \\
\hline Total & 246940414 & 313 & 788947.01 & & \\
\hline Bequest & Coef. & Std. err. & $T$ & $p>|t|$ & Beta \\
\hline Sex, male & 249.00 & 110.60 & 2.25 & 0.025 & 0.14 \\
\hline Education & 99.76 & 59.10 & 1.69 & 0.092 & 0.10 \\
\hline Period lived & 4.65 & 4.46 & 1.04 & 0.298 & 0.09 \\
\hline Distance $(\mathrm{km})$ & 5815725.00 & 10.31 & 0.06 & 0.955 & 0.00 \\
\hline $\mathrm{HH}$ size & 18.86 & 21.21 & 0.89 & 0.375 & 0.05 \\
\hline Land size & 7.93 & 7.40 & 1.07 & 0.285 & 0.08 \\
\hline TLU & 34.87 & 15.98 & 2.18 & 0.030 & 0.16 \\
\hline Income & -0.00005 & 0.0002 & -0.23 & 0.818 & -0.01 \\
\hline Age & -16.76 & 6.26 & -2.68 & 0.008 & -0.22 \\
\hline Cons & 823.56 & 271.85 & 3.03 & 0.003 & \\
\hline
\end{tabular}

Worth noting, nonuse/passive values referred to in other literature as existence values [39] include biodiversity, scenery, recreational/spiritual values, aesthetic enjoyment, and intrinsic values [42-46]. On cultural/spiritual values, the study records, the level of education, age, and income influence the maximum WTP, whereby the higher level of education and income resulted in enhanced maximum WTP while an increase in age negatively influences the maximum WTP on cultural values. The other important one, though slightly significant, is the more the period lived within the ecosystem, the higher the maximum WTP. Most importantly, the beauty of the ecosystem and the value attached to 
TABLE 10: Biodiversity conservation as a function of socioeconomic parameters.

\begin{tabular}{|c|c|c|c|c|c|}
\hline Source & SS & Df & MS & \multicolumn{2}{|c|}{$\begin{array}{c}\text { Number of Obs }=274 \\
F_{(9,264)}=3.80\end{array}$} \\
\hline Model & 48020408.2 & 9 & 5335600.91 & \multicolumn{2}{|c|}{ Prob $>F=0.0002$} \\
\hline Residual & 370262256 & 264 & 1402508.55 & \multirow{2}{*}{\multicolumn{2}{|c|}{$\begin{array}{c}R \text {-squared }=0.1148 \\
\text { Adj. } R \text {-squared }=0.0846 \\
\text { Root } \mathrm{MSE}=1184.3\end{array}$}} \\
\hline Total & 418282664 & 273 & 1532170.93 & & \\
\hline Sustainability & Coef. & Std. err. & $\mathrm{T}$ & $p>|t|$ & Beta \\
\hline Sex, male & 261.38 & 174.13 & 1.50 & 0.135 & 0.11 \\
\hline Education & 12.87 & 89.14 & 0.14 & 0.885 & 0.01 \\
\hline Period lived & 10.35 & 6.96 & 1.49 & 0.138 & 0.15 \\
\hline Distance $(\mathrm{km})$ & 12.27 & 16.13 & 0.76 & 0.447 & 0.05 \\
\hline $\mathrm{HH}$ size & -13.56 & 31.06 & -0.44 & 0.663 & -0.03 \\
\hline Land size & 6.43 & 12.80 & 0.50 & 0.616 & 0.04 \\
\hline TLU & 62.77 & 24.23 & 2.59 & 0.010 & 0.18 \\
\hline Income & -.0010 & 0.0005 & -2.19 & 0.030 & -0.15 \\
\hline Age & -26.72 & 9.53 & -2.80 & 0.005 & -0.26 \\
\hline Cons & 1637.77 & 406.78 & 4.03 & 0.000 & \\
\hline
\end{tabular}

it are influenced by the sociocultural traits held by the community around it. Though observers' attachment of culture is reported differently from the literature, the majority agree with sentiment with the literature on valuation of cultural/spiritual values that "there is no doubt that the valuation of the scenic beauty of forests is affected by the different cultural and social traits held by the observers" [47-49].

On the other hand, bequest also referred to as "sustainability" value in some literature [39] records sex, age, and TLU of the respondent to influence the maximum WTP, while, for instance, an increase in the age of an individual reduces the maximum WTP. On respondent sex, male respondents were likely to pay more than their female counterparts. The other factors include TLU and the period lived in the area whereby an increase positively influences the maximum WTP. Similarly, the higher the livestock owned by HH, the higher the maximum WTP. On the other hand, the willingness to pay for biodiversity conservation recorded a negative correlation in respect to the respondent's age and income, contrary to a study in the Philippines on a ridge to reef ecosystem-based valuation [40], and a positive correlation on TLU and period lived in the area. Partly though, sex is also reported to influence the maximum WTP, whereby male individuals are seen to have attached a higher value to biodiversity conservation service than their female counterparts.

Overall, the individual willingness to pay on nonuse value ranged between 1 USD and 95.2 USD, with a Mean \pm SD WTP per capita per annum estimated at $7.4 \pm 0.3$ USD, $9.1 \pm 0.5$ USD, and $11.1 \pm 0.7$ for the cultural, bequest, and biodiversity conservation, respectively. Cumulatively, a majority $(\sim 80 \%)$ of the respondents were willing to pay between 1 USD and 10 USD while less than $20 \%$ of the respondents were willing to pay more than 10 USD for all the services quoted and bided. The aggregated estimates would be reported to be within the range of most of the literature $[11,40,49-54]$ on nonuse values that reported more than $90 \%$ of the targeted respondents quoted between 1 USD and 100 USD for nonuse values.

\section{Conclusions}

Although there was significant variability in the monetary value quoted on the nonuse ecosystem benefits, the local community appreciates ecological conservation even though it does not necessarily benefit directly. This was evident from the majority (97\%) of the population that was willing to pay even though such schemes would attract cost to the benefiting community when established. This is a reflection on the preference of the society to sustainably conserve the water catchment ecosystem as it believes to support human wellbeing both directly and indirectly. The findings agree with most literature that revealed that ecosystems have high economic value since the society believes it is critical on the socioeconomic agenda and livelihood [53-57]. Nonetheless, parameters such as the location and socioeconomic and cultural respondent traits influence the mean maximum willingness to pay for nonuse values. This is fundamentally based on an individual level of understanding and perception of ecosystem benefits. Critically though, in addition to the area of the respondent, the age of the population seems to influence the maximum WTP across the non-use cohort, where the younger population is reported to attach high value compared to older folks.

Nonetheless, as the society explores the valuation of nonmarketed ecosystem products using stated preference, there will be a need to distinguish between genuine WTP and "push away" quoted values. The study estimates are not absolute, and thus, the generalization of findings to the entire population can be applied with caution because of the limitation that includes the "push away" values and low level of understanding of the importance of valuation. Nonetheless, in the absence of other local studies on the valuation of non-use values, the findings estimate can still be used while taking into consideration the limitation stated. These values could also form a basis of policy reviews and support of sound decision making, particularly on forest conservation locally [11].

The acceptability by a majority would also support the establishment of schemes such as payment of ecosystem 
services (PES) and forest enhancement policies. PES establishment will facilitate and support the promotion of farm forestry and agroforestry, thus reducing pressure and overreliance on state forest while complying with UN SDGs, particularly No. 15 (life on Land) on sustainable land and forest management. The findings should provoke the establishment of forest enhancement policies such as reforestation, subsiding LPG and electricity, and advocacy on forest conservation to reduce forest degradation. This effort should be complemented by the local community, state, and nonstate actors to conserve already shrinking ecosystems.

The study can be a baseline for the application of nonmarketed ES valuation techniques locally; however, the study recommends further explicit exploration on other stated preference techniques such as the choice experiment model or conjoint locally either for comparison or unravelling the techniques' uncertainties. Ultimately, a strong justification for the application of such data in the development of PES schemes in Kenya, local policy reviews, and project appraisals is built.

\section{Data Availability}

The [Contingency Valuation] data used to support the findings of this study are attached as a supplementary file and would also be made available from the corresponding author upon request (e-mail: jeregae@gmail.com).

\section{Conflicts of Interest}

The authors declare no conflicts of interest.

\section{Acknowledgments}

The team is highly indebted to research assistant Humphrey Lotem, who led the data collection process and as a crew guide. Sincere gratitude goes to the Chief Conservator of the Kenya Forest Service. Appreciation goes to the Kenya Higher Education Loans Board (HELB) and Institute of Energy and Environmental Technology (IEET) of Jomo Kenyatta University of Agriculture Technology (JKUAT) for their facilitation. The authors also appreciate other group members including the local administrator, community, and enumerators that provided the required support in the entire study.

\section{Supplementary Materials}

The supplementary file is the household survey data including the response on willingness to pay meant to support the article. (Supplementary Materials)

\section{References}

[1] I. J. Bateman, G. M. Mace, C. Fezzi, G. Atkinson, and K. Turner, "Economic analysis for ecosystem service assessments," Environmental and Resource Economics, vol. 48, no. 2, pp. 177-218, 2011.

[2] R. De Groot, B. Fisher, M. Christie et al., "Integrating the ecological and economic dimensions in biodiversity and ecosystem service valuation," in The Economics of Ecosystems and Biodiversity: The Ecological and Economic Foundations, Earthscan, London, UK, 2009.

[3] Haines-Young and M. Potschin, "Prioritization of ecosystem services for ecosystem accounting," in Proceedings of the expert meeting on ecosystem accounts organized by the UNSD, the EEA, and the World Bank, London, UK, December 2011, https://unstats.un.org/unsd/envaccounting/ seeaLES/\%0Aegm/Issue8a.pdf.

[4] MEA, Ecosystems and Human Well-Being: Current State and Trends Assessment, Island Press, Washington, DC, USA, 2005.

[5] U. Pascual, R. Muradian, L. Brander et al., The Economics of Valuing Ecosystem Services and Biodiversity, Earthscan, London, UK, 2010.

[6] TEEB, The Economics of Ecosystems and Biodiversity Ecological and Economic Foundations, P. Kumar, Ed., Earthscan, London, UK, 2010.

[7] United Nations, System of Environmental-Economic Accounting 2012: Applications and Extensions, European Commission, Organisation for Economic Co-operation and Development, Paris, France, 2017, https://unstats.un.org/ unsd/envaccounting/seeaRev/ahttps://unstats.un.org/unsd/\% 0 Aenvaccounting/seeaRev/ae_final_en.pdf.

[8] TEEB, "Integrating ecosystem and biodiversity values into policy assessment," in The Economics of Ecosystems and Biodiversity: TEEB for National and International Policymakers, 2009, https://www.teebweb.org/wp-content/uploads/ 2013/04/TEEB-for-POLICYMAKERS-Chapter-4.pdf.

[9] M. Masiero, D. Pettenella, M. Boscolo, S. Barua, I. Animon, and J. R. Matta, Valuing Forest Ecosystem Services A Training Manual For Planners And Project Developers, FAO, Rome, Italy, 2019, http://www.wipo.int/amc/en/mediation/rules.

[10] S. Wunder, Payments For Environmental Services: Some Nuts And Bolts, Centre for International Forestry Research (CIFOR), Bogor, Indonesia, 2005.

[11] C. Dobbs, M. Martinez-Harms, and D. Kendal, "Ecosystem services," in F. Ferrini, C. Konijnendijk van den Bosch \& A. Fini, eds., Routledge Handbook of Urban Forestry, Routledge, Abingdon, UK, 2017.

[12] I. Diafas, Estimating the Economic Value of Forest Ecosystem Services Using Stated Preference Methods: The Case of Kakamega Forest, Georg-August-University Göttingen, Göttingen, Germany, 2014.

[13] B. Martín-López, C. Montes, and J. Benayas, "The role of user's characteristics on the ecosystem services valuation: the case of Doñana Natural Protected Area (SW, Spain)," Environmental Conservation, vol. 34, pp. 2015-2024, 2007.

[14] S. Liu, R. Costanza, S. Farber, and A. Troy, "Valuing ecosystem services Theory, practice, and 78 the need for a transdisciplinary synthesis," Annals of the New York Academy of Sciences, vol. 1185, pp. 54-78, 2010.

[15] TEEB, The Economics of Ecosystems \& Biodiversity, TEEB, Wellington, New Zealand, 2008.

[16] W. L. Adamowicz, "What's it worth? An examination of historical trends and future directions in environmental valuation*," The Australian Journal of Agricultural and Resource Economics, vol. 48, no. 3, pp. 419-443, 2004.

[17] K. M. A. Chan, T. Satterfield, and J. Goldstein, "Rethinking ecosystem services to better address and navigate cultural value," Ecological Economics, vol. 74, no. 8-18, 2012.

[18] T. Daniel, A. Muhar, A. Arnberger, O. Aznarc et al., "Contributions of cultural services to the ecosystem services agenda," Proceedings of the National Academy of Sciences of the United States of America, vol. 109, pp. 8812-8819, 2012. 
[19] E. J. Sattout, S. N. Talhouk, and P. D. S. Caligari, "The economic value of cedar relics in Lebanon: an application of contingent valuation method for conservation," Ecological Economics, vol. 61, pp. 315-322, 2007.

[20] M. Jean-Baptiste, B. Luke, T. Olivier et al., "Non-market use and non-use values for preserving ecosystem services over time: a choice experiment application to coral reef ecosystems in New Caledonia," Ocean \& Coastal Management, vol. 105, pp. 1-14, 2015.

[21] T. O'Garra, "Bequest values for marine resources: how important for indigenous communities in less-developed economies," Environmental and Resource Economics, vol. 44, pp. 179-202, 2009.

[22] P. Wattage and S. Mardle, "The total economic value of wetland conservation in Sri Lanka identifying use and nonuse values," Wetlands Ecology and Management, vol. 16, 2008.

[23] A. Kontogianni, C. Tourkolias, A. Machleras, and M. Skourtos, "Service providing units, existence values and the valuation of endangered species: a methodological test," Ecological Economics, vol. 79, pp. 97-104, 2012.

[24] R. Costanza, R. D’ Arge, R. de Groot et al., "The value of the world's ecosystem services and natural capital," Nature, vol. 387, pp. 253-260, 1997.

[25] I. O. Monica, S. M. Alex, and D. S. Barry, "Economic valuation of environmental services sustained by water flows in the Yaqui River Delta," Ecological Economics, vol. 65, pp. 155-166, 2008.

[26] J. B. Loomis, "Measuring the economic benefits of removing dams and restoring the Elwha river: results of a contingent valuation survey," Water Resources Research, vol. 32, no. 2, pp. 441-447, 1996.

[27] J. B. Loomis, "Measuring the total economic value of restoring ecosystem services in an impaired river basin: results from a contingent valuation survey," Ecological Economics, vol. 33, pp. 103-117, 2000.

[28] Z. Zhang, XuZhongming, and G. Cheng, "The updated development and application of contingent valuation method," Advances in Earth Science, vol. 18, no. 3, pp. 454-463, 2003.

[29] L. Venkatachalam, "The contingent valuation method," Environmental Impact Assessment Review, vol. 24, pp. 89-124, 2004.

[30] NZIER, What's the Use of Non-use Values? Non-use Values and the Investment Statement Revised New Zealand Institute of Economic Research (NZIER) Report to the Treasury, NZIER, Wellington, New Zealand, 2018.

[31] R. Perman, Y. Ma, M. Common, D. Maddison, and J. McGilvray, Natural Resource and Environmental Economics, Pearson Education Ltd, London, UK, 2011.

[32] P. M. Njogu, J. J. Keriko, and J. M. Kitetu, "Sustainable ecosystem management versus economic exploitation: a case study of Lake naivasha basin, Kenya," Journal of Environmental Science and Engineering, vol. 4, no. 7, pp. 50-55, 2010.

[33] KWTA, Elgeyo Hills Water Tower Conservation Plan (ECP) (2020-2030), Kenya Water Tower Agency, Nairobi, Kenya, 2020.

[34] CGoEM, County Integrated Development Plan-Elgeyo Marakwet County (CIDP), CGoEM, Limassol, Cyprus, 2018.

[35] KNBS, 2019 Kenya Population and Housing Census: Volume II, KNBS, Nairobi, Kenya, 2019.

[36] MoALF, Agricultural Sector Development Support Programme (ASDSP); Vol.I Household Baseline Survey Report, MoALF, Elgeyo Marakwet County, Kenya, 2014.
[37] O. M. Mugenda and A. O. Mugenda, Research Methods. Quantitative and Qualitative Approaches, Act Press, Rome, Italy, 1999.

[38] D. R. Petrolia, M. G. Interis, and J. Hwang, "America's wetland? A national survey of willingness to pay for the restoration of Louisiana's coastal wetlands," Marine Resource Economics, vol. 29, pp. 17-37, 2014.

[39] D. Bamwesigye, P. Hlavackova, A. Sujova, J. Fialova, and P. Kupec, "Willingness to pay for forest existence value and sustainability," Sustainability, vol. 12, no. 891, p. 16pp, 2020.

[40] J. C. P. Ureta, R. D. Lasco, A. J. U. Sajise, and M. M. Calderon, "A Ridge-to-Reef ecosystem-based valuation approach to biodiversity conservation in layawan watershed, misamis Occidental, Philippines," Journal of Environmental Science and Management, vol. 19, no. 2, pp. 64-75, 2016.

[41] P. Chou, "The role of non-timber forest products in creating incentives for forest conservation: a case study of Phnomprich wildlife sanctuary, Cambodia," Resources, vol. 7, p. 41, 2018.

[42] M. Bösch, P. Elsasser, K. Franz et al., "Forest ecosystem services in rural areas of Germany: insights from the national TEEB study," Ecosystem Services, vol. 31, pp. 77-83, 2018.

[43] D. L. Dickinson, J. C. Whitehead, Dubious, and Dubiouser, "Contingent valuation and the time of day," Economic Inquiry, vol. 53, pp. 1396-1400, 2015.

[44] N. N. Kharchenko, S. S. Morkovina, D. Y. Kapitonov, and O. S. Lisova, "Forest ecosystem services in the system of sustainable forest use of sparsely forested regions of Russia," Journal of Engineering and Applied Science, vol. 13, pp. 3567-3572, 2018.

[45] M. J. Kotchen, Z. M. Turk, and A. A. Leiserowitz, "Public willingness to pay for a US carbon tax and preferences for spending the revenue," Environmental Research Letters, vol. 12, 2017.

[46] N. Sawe, "Using neuroeconomics to understand environmental valuation," Ecological Economics, vol. 135, pp. 1-9, 2017.

[47] D. Edwards, M. Jay, F. Jensen et al., "Public preferences for structural attributes of forests: towards a pan-European perspective," Forest Policy and Economics, vol. 19, pp. 12-19, 2012.

[48] N. Eisenhauer, A. C. Sabais, and S. Scheu, "Collembola species composition and diversity effects on ecosystem functioning vary with plant functional group identity," Soil Biology and Biochemistry, vol. 43, pp. 1697-1704, 2011.

[49] R. Paudyal, T. Stein, H. Ober, M. Swisher, E. Jokela, and D. Adams, "Recreationists' perceptions of scenic beauty and satisfaction at a public forest managed for endangered wildlife," Forests, vol. 9, p. 241, 2018.

[50] P. Fix, J. Carroll, and A. Harrington, "Visitor experiences across recreation settings: a management or measurement issue," Journal of Outdoor Recreation Tour, vol. 3, no. 4, pp. 28-35, 2013.

[51] A. R. Kearney and G. A. Bradley, "The effects of viewer attributes on preference for forest scenes: contributions of attitudes, knowledge, demographic factors, and stakeholder group membership," Environment and Behavior, vol. 43, pp. 147-181, 2010.

[52] E. Ojea, P. Nunes, and M. Loureiro, "Mapping biodiversity indicators and assessing biodiversity values in global forests," Environmental and Resource Economics, vol. 47, pp. 329-347, 2010.

[53] N. Suzuki and K. L. Parker, "Proactive conservation of highvalue habitat for woodland caribou and grizzly bears in the 
boreal zone of British Columbia, Canada," Biological Conservation, vol. 230, pp. 91-103, 2019.

[54] L. A. Wainger, R. Helcoski, K. W. Farge, B. A. Espinola, and G. T. Green, "Evidence of a shared value for nature," Ecological Economics, vol. 154, pp. 107-116, 2018.

[55] M. Christie, N. Hanley, J. Warren, K. Murphy, R. Wright, and T. Hyde, "Valuing the diversity of biodiversity," Ecological Economics, vol. 58, pp. 304-317, 2006.

[56] M. Christie and M. Rayment, "An economic assessment of the ecosystem service benefits derived from the SSSI biodiversity conservation policy in England and Wales," Ecosystem Services, vol. 1, pp. 70-84, 2012.

[57] A. Jordan and D. Russel, "Embedding the concept of ecosystem services? The utilization of ecological knowledge in different policy venues," Environmental Planning C: Politics and Space, vol. 32, pp. 192-207, 2014. 